\title{
SPATIALIZATION OF ELECTRICAL CONDUCTIVITY AND PHYSICAL HYDRAULIC PARAMETERS OF SOILS UNDER DIFFERENT USES IN AN ALLUVIAL VALLEY ${ }^{1}$
}

\author{
IUG LOPES ${ }^{2}$, ABELARDO ANTÔNIO DE ASSUNÇÃO MONTENEGRO ${ }^{3 *}$
}

\begin{abstract}
Evaluating spatial variability of hydraulic properties and salinity of soils is important for an adequate agricultural management of alluvial soils, and protection of riparian vegetation. Thus, the objective of this work was to evaluate the accuracy of geophysical techniques for indirect measurements of apparent electrical conductivity (ECa), using an electromagnetic induction equipment $\left(\mathrm{EM} 38^{\circledR}\right)$, and soil physical hydraulic parameters and their spatial interrelations. The study was carried out at the Advanced Research Unit of the UFRPE, in the Brígida River Basin, in Panamirim, state of Pernambuco, Brazil, in the second half of 2016. This river had a $100 \mathrm{~m}$ wide riparian forest strip transversely to the river bank on both sides of the river. A regular $20 \times 10 \mathrm{~m}$ grid with 80 points was used to evaluate the soil hydraulic conductivity and ECa. The geostatistics showed the spatial dependence and the dependence of the soil attributes, their spatialization, and precise mapping through indirect readings. Most of the variability $(86 \%)$ in soil electrical conductivity was explained by indirect readings using the EM $38^{\circledR}$. Ranges of $80 \mathrm{~m}, 380 \mathrm{~m}$, and $134 \mathrm{~m}$ were found for soil moisture, ECa, and hydraulic conductivity, respectively, presenting strong spatial dependence. The results showed the importance of riparian forests to the maintenance of soil moisture and porosity to the improvement of soil water infiltration capacity even under severe water deficit conditions and soil subsurface layers.
\end{abstract}

Keywords: EM38. Ecosystem services. Soil use. Beerkan. Geostatistics.

\section{ESPACIALIZAÇÃO DA CONDUTIVIDADE ELÉTRICA E PARÂMETROS FÍSICO-HÍDRICOS SOB DIFERENTES USOS EM REGIÃO ALUVIAL}

RESUMO - A caracterização da estrutura de variabilidade espacial de propriedades hidráulicas e da salinidade do solo é de grande importância para um adequado manejo agrícola de vales aluviais e para proteção da vegetação ciliar. Dessa forma, o objetivo deste trabalho foi a verificação da precisão de medições indiretas da condutividade elétrica aparente $(\mathrm{CEa})$ utilizando o $\mathrm{EM} 38^{\circledR}$, bem como de parâmetros físico-hídricos do solo, e suas inter-relações espaciais. O estudo foi desenvolvido na Unidade Avançada de Pesquisa da UFRPE, localizada na Bacia do Rio Brígida, município de Panamirim-PE, no período do segundo semestre de 2016, possuindo uma faixa de mata ciliar de $100 \mathrm{~m}$ de largura, transversalmente a cada margem do rio. Adotou-se uma área com malha regular $20 \times 10 \mathrm{~m}$, totalizando 80 pontos, onde foram feitas avaliações da condutividade hidráulica e a calibração da $\mathrm{CEa}$. A utilização da geoestatística permitiu identificar a dependência espacial e a dependência de todos atributos estudados, possibilitando sua espacialização e a utilização das leituras indiretas no mapeamento de precisão. Verificou-se que $86 \%$ da variabilidade da condutividade elétrica do solo pode ser explicada pelas leituras indiretas com o equipamento de indução eletromagnética (EM38 ${ }^{\mathbb{B}}$ ). Os valores de alcance foram de $80 \mathrm{~m}, 380 \mathrm{~m}$ e $134 \mathrm{~m}$ foram obtidas para a umidade do solo, CEa e condutividade hidráulica, respectivamente, as quais apresentaram forte dependência espacial. Verificou-se a relevância da mata ciliar na manutenção de umidade e porosidade do solo e, principalmente, contribuição para uma maior capacidade de infiltração do solo, mesmo para condições severas de escassez, e para as camadas sub-superficiais do mesmo.

Palavras-chave: EM38. Serviços ecossistêmicos. Uso de solo. Beerkan. Geoestatística.

\footnotetext{
${ }^{*}$ Corresponding author

${ }^{1}$ Received for publication in 07/02/2017; accepted in 01/31/2019.

Paper extracted from the doctoral thesis of the first author.

${ }^{2}$ Department of Agronomy, Instituto Federal de Educação, Ciência e Tecnologia Baiano, Bom Jesus da Lapa, BA, Brazil; iug.lopes@ifbaiano.edu.br - ORCID: 0000-0003-0592-4774.

${ }^{3}$ Department of Agricultural Engineering, Universidade Federal Rural de Pernambuco, Recife, PE, Brazil; abelardo.montenegro@ufrpe.br ORCID: 0000-0002-5746-8574.
} 


\section{INTRODUCTION}

Soil spatial information has been increasingly required for decision-making regarding the environment, and land use managements (BORRELLI et al., 2014). The spatial variability of soil attributes, which can be evaluated by geostatistics techniques, is important for the management of agricultural areas (LABORCZI et al., 2015).

Alluvial valleys have strategic importance for the Brazilian semiarid region; they determine water flow and soil water storage capacity in both saturated and unsaturated zones (MONTENEGRO; MONTENEGRO, 2006). From the ecohydrological point of view, these valleys favor the development of riparian vegetation, which intercepts precipitation, favoring water infiltration into the soil. Vidon (2013) described the connection between riparian vegetation and the potentiometric dynamics of the alluvial water table, and spatial and temporal variabilities of nutrients (phosphorus and nitrogen).

The apparent electrical conductivity $(\mathrm{ECa})$ is a soil property that can represent a set of other properties. The main soil properties of agricultural importance that influence the ECa are salinity, water content, texture, and chemical attributes (RHOADES et al., 1989; MOLIN; FAULIN, 2013).

Corwin and Lesch (2003); Corwin (2005) reported the efficiency of geophysical techniques based on electromagnetic readings with an electromagnetic induction equipment $\left(\mathrm{EM} 38^{\circledR}\right)$ in precision agriculture. However, their quality is dependent on accurately calibration of this tool, especially in areas with high spatial heterogeneities, such as alluvial valleys and riparian zones (THIESSON et al., 2014; MONTENEGRO et al., 2010). Schlosser et al. (2013) applied geophysical techniques of electrical resistivity in an alluvial valley, following transects transverse to the main water course, to evaluate the dynamics of unsaturated flows during rainfall events. Such flows are important to increase the ecosystem services associated with riparian vegetation.

Geophysical readings can vary according to the spatial distribution of soil hydraulic properties and salinity (MONTENEGRO; MONTENEGRO, 2006). Precision agriculture requires a very large number of samples to accurately represent variabilities. Some approaches are used to define structural variance, distribution, and trends in soil properties (GUO et al., 2015). According to Yao, Yang and Liu (2007), obtaining moisture, texture, and density parameters, and indirectly, hydraulic conductivity is important because they are related to the electromagnetic induction data.

Chemical and physical attributes of cultivated soils may change depending on the use intensity, preparation, and cultural practices used, and may have negative consequences for the crop production. Thus, using favorable agricultural techniques, and preservation of areas in rotation systems are important. Maintenance of preservation and riparian areas can improve water retention and decrease soil loss of agricultural areas (OLIVEIRA JUNIOR et al., 2014).

In this context, the objective of this work was to evaluate the accuracy of geophysical techniques for indirect measurements of apparent electrical conductivity (ECa) using an electromagnetic induction equipment $\left(\mathrm{EM} 38^{\circledR}\right)$, characterize the spatial variability of soil moisture and salinity, and evaluate soil variables of a riparian zone of the Brígida River Basin (for ecosystem services purposes), and physical hydraulic parameters of soils with different uses under severe water deficit in its alluvial valley (semiarid region of the state of Pernambuco, Brazil).

\section{MATERIAL AND METHODS}

\section{Area description}

Hydraulic parameters, electrical conductivity, and soil texture were evaluated in an area in Parnamirim, semiarid region of Pernambuco, Brazil. An area of an alluvial valley $\left(08^{\circ} 05^{\prime} 08^{\prime \prime} \mathrm{S} ; 39^{\circ}\right.$ 34 '27"W) of the Area of Advanced Research Unit of the Rural Federal University of Pernambuco (UFRPE) was studied. This area is in the Brígida River Basin, downstream the Fomento Dam.

Field sampling was carried out in the second half of 2016, a period of extreme water deficit in the region (LOPES et al., 2017; LOPES et al., 2018), which can be confirmed by the precipitation of the previous year and by the historical data series of 1990-2016 (Figure 1). 


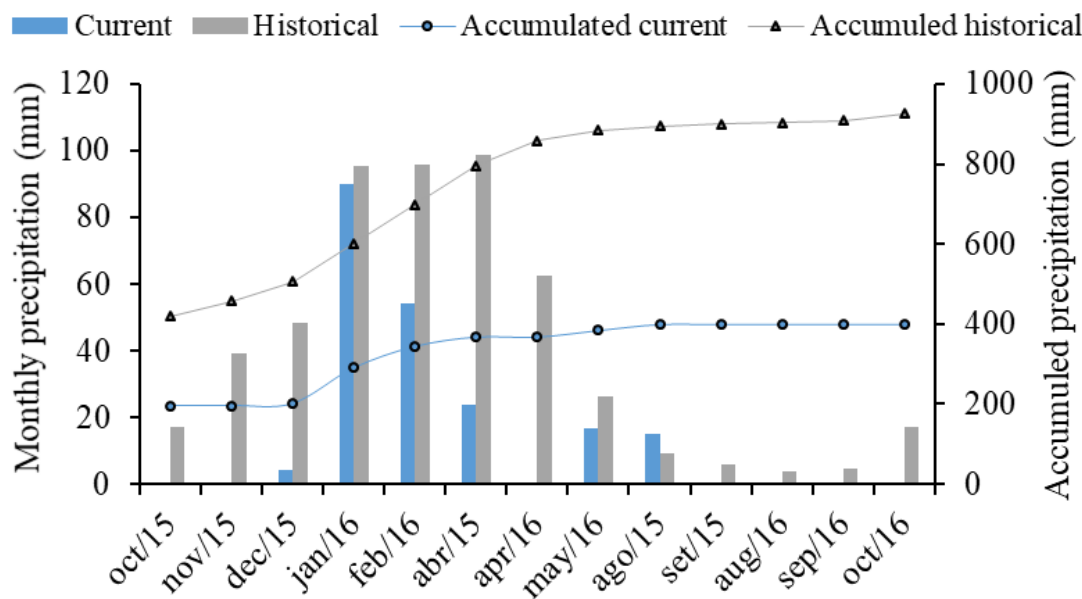

Figure 1. Monthly and accumulated precipitation for the historical data series of 1961 to 2016, and for 2016.

\section{Sampling and analysis}

The study area had 2.8 ha (Figure 2), with three different uses (coverages) - preservation area (arboreous Caatinga vegetation) (A1); fallow area (A2); and soil preparation area (A3).

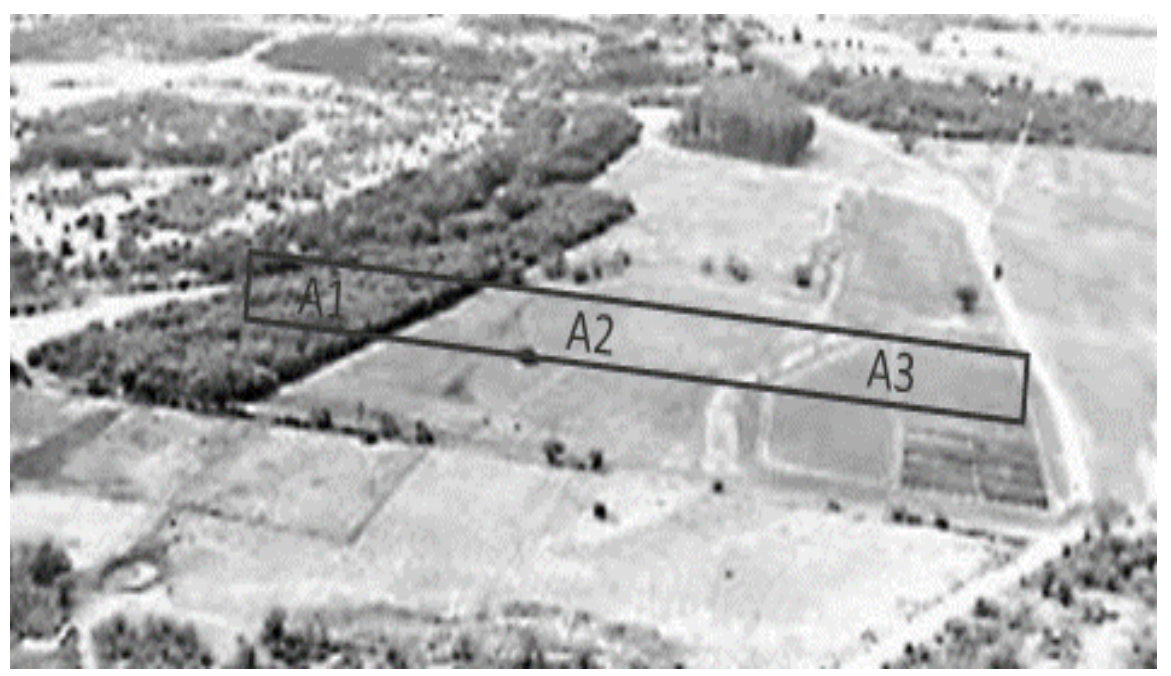

Figure 2. Aerial depiction of the studied areas with preservation area (arboreous Caatinga vegetation) (A1); fallow area (A2); and soil preparation area (A3).

The soil use, vegetation cover, and agricultural use of the areas were different. A regular grid of $20 \times 10 \mathrm{~m}$ ( 80 points) was used to sample soil moisture and soil hydraulic conductivity; and a regular grid of $10 \times 10 \mathrm{~m}$ (152 points) was used to sample the soil apparent electrical conductivity (ECa) using electromagnetic inductions, with four horizontal points.

The soil of the area was classified as Fluvic Neosol of clayey loam texture in the $0-0.3 \mathrm{~m}$ layer, with means of $46 \%$ of sand, 28.9 of silt, and $25 \%$ of clay. The $0.3-0.6 \mathrm{~m}$ layer presented means of $31.89 \%$ of sand, $44.51 \%$ of silt, and $23.60 \%$ of clay; and the $0.6-0.9 \mathrm{~m}$ layer presented means of $30.32 \%$ of sand, $42.35 \%$ of silt, and $27.33 \%$ of clay.

\section{Apparent electrical conductivity (ECa)}

The electromagnetic induction was used in vertical and horizontal modes with an electromagnetic induction equipment $\left(\mathrm{EM} 38^{\circledR}\right)$ positioned at different heights in relation to the ground level $(0,0.3,0.6,0.9,1.2$, and $1.5 \mathrm{~m})$, as recommended by Rhoades and Corwin (1981) and Montenegro et al. (2010).

This procedure provided a system of equations that can be used to evaluate the soil ECa profile through regression functions.

The following regression functions were used to evaluate the soil electrical conductivity, and electromagnetic induction readings:

1. Functions of Rhoades and Corwin (1981):

The equations proposed by Rhoades and Corwin (1981) (Table 1) involve five heights of the $\mathrm{EM} 8^{\circledR}(0,0.3,0.6,0.9$, and $1.2 \mathrm{~m}$ represented by the indexes $0,1,2,3$, and 4 , respectively). 
Table 1. Equations used in the methodology.

\begin{tabular}{|c|c|c|c|c|}
\hline Soil layer $(\mathrm{m})$ & \multicolumn{3}{|c|}{ Equation for electrical conductivity - Rhoades e Corwin (1981) } & Equation \\
\hline $\begin{array}{c}0-0.3 \\
0.3-0.6 \\
0.6-0.9 \\
0.9-1.2 \\
\end{array}$ & \multicolumn{3}{|c|}{$\begin{array}{c}-0.1285 \mathrm{EM}_{0}+0.1446 \mathrm{EM}_{1}+5.3878 \mathrm{EM}_{2}-17.4476 \mathrm{EM}_{3}+15.0549 \mathrm{EM}_{4}-0.1309 \\
-1.3259 \mathrm{EM}_{1}+4.8938 \mathrm{EM}_{2}+55.8250 \mathrm{EM}_{3}-94.0405 \mathrm{EM}_{4}+47.4196 \mathrm{EM}_{4}-0.9169 \\
9.1705 \mathrm{EM}_{0}-8.4116 \mathrm{EM}_{1}-18.3090 \mathrm{EM}_{2}+50.6298 \mathrm{EM}_{3}-42.5033 \mathrm{EM}_{4}-0.1224 \\
1.1090 \mathrm{EM}_{0}+0.2352 \mathrm{EM}_{1}-23.3536 \mathrm{EM}_{2}+221.0100 \mathrm{EM}_{3}-266.8789 \mathrm{EM}_{4}-3.5012\end{array}$} & $\begin{array}{l}\text { (1a) } \\
(1 \mathrm{~b}) \\
(1 \mathrm{c}) \\
\text { (1d) }\end{array}$ \\
\hline Soil layer $(\mathrm{m})$ & Equation for electrical conductivity - Rhoades et al. (1989) & $\mathrm{N}$ & $\mathrm{R}^{2}$ & Equation \\
\hline $\begin{array}{c}0-0.3 \\
0.3-0.6 \\
0.6-0.9\end{array}$ & 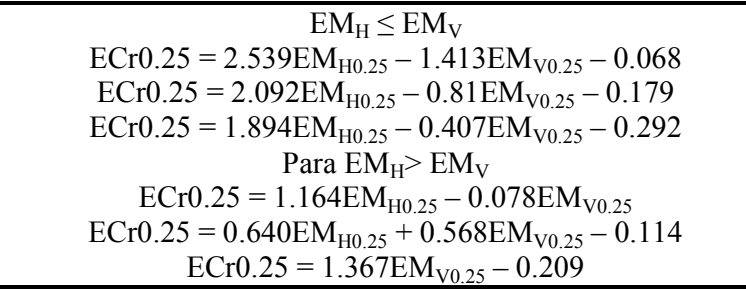 & $\begin{array}{l}759 \\
761 \\
758\end{array}$ & $\begin{array}{l}0.922 \\
0.969 \\
0.919 \\
\end{array}$ & $\begin{array}{l}(2 a) \\
(2 b) \\
(2 c)\end{array}$ \\
\hline Soil layer $(\mathrm{m})$ & \multicolumn{3}{|c|}{ Equation for electrical conductivity - Rhoades, Chanduvi and Lesch (1999) } & Equation \\
\hline $\begin{array}{c}0-0.3 ; 0.3-0.6 \\
\text { and } 0.6-0.9\end{array}$ & \multicolumn{3}{|c|}{$\ln \left(\mathrm{EM}_{\mathrm{H}}\right)-\ln \left(\mathrm{EM}_{\mathrm{V}}\right) 0.04334+0.03058 \ln \left(\mathrm{EM}_{\mathrm{H}}\right)+0.00836\left(\mathrm{EM}_{\mathrm{H}}\right)^{2}$} & (3) \\
\hline & \multicolumn{3}{|l|}{ Equation for electrical conductivity - Beerkan } & $\frac{\text { Equation }}{(4)}$ \\
\hline
\end{tabular}

2. Functions of Rhoades et al. (1989):

The equations $2 \mathrm{a}, 2 \mathrm{~b}, 2 \mathrm{c}, 2 \mathrm{~d}, 2 \mathrm{e}$, and $2 \mathrm{f}$ (Figure 1) are based on the fourth root transformation of the horizontal and vertical readings, considering the equipment positioned only at the soil surface level. (1999):

3. Functions of Rhoades; Chanduvi; Lesch

Rhoades, Chanduvi and Lesch (1999) developed linear relationships between the Napierian logarithm of $\mathrm{EM}_{\mathrm{H}}$ (horizontal $\mathrm{EM} 38^{\circledR}$ ) and the difference between $\ln \left(\mathrm{EM}_{\mathrm{H}}\right)-\ln \left(\mathrm{EM}_{\mathrm{V}}\right)\left(\mathrm{EM}_{\mathrm{V}}\right.$-vertical $\mathrm{EM} 38^{\circledR}$ ) to remove the collinearity between the horizontal and vertical readings of the EM $38^{\circledR}$, as found by Lesch et al. (1992). The relation $\ln \left(\mathrm{EM}_{\mathrm{H}}\right)$ $\ln \left(\mathrm{EM}_{\mathrm{V}}\right)$ of the measures was established for regular profiles, less than $5 \%$ of the theoretical $\ln \left(\mathrm{EM}_{\mathrm{H}}\right)-\ln$ $\left(\mathrm{EM}_{\mathrm{V}}\right)$.

The mathematical models, relating the type of profile and the logarithm of apparent conductivities, were developed for the 0-0,3, 0.3-0.6, and 0.6-0.9 m soil layers, positioning the equipment on the soil surface.

\section{Beerkan Methodology}

The Beerkan methodology was used with simple rings of radius of 0.075 (HAVERKAMP et al., 1998; LASSABATÈRE et al., 2006) to evaluate physical hydraulic parameters, in 78 points. It has advantage over other experimental methods because of the reduced time, and high efficiency of its application (HAVERKAMP et al., 1998).

This method is applied to represent the water infiltration into the soil on a local scale, allowing the adjust of soil water infiltration curves to determine hydraulic conductivity of the saturated soil (Ks) (Table 1, Equation 4). The equation is composed of an angular parameter of the linearized equation of the line (b1); and four values $(0.036,0.012,0.004$, and $0.001 \mathrm{~mm}$ ) corresponding to soils ranging from coarse sand to compacted clays $(\alpha)$. An $\alpha$ of 0.004 $\mathrm{mm}$ was taken as the first approximation for most clayey loam soils, thus, it was applied for such verification.

\section{Determination of soil moisture}

Disturbed soil samples (78 samples) of the layers described in Table 1 were collected with an auger, placed in hermetically sealed containers, and taken to a laboratory to measure their moisture by the gravimetric method (EMBRAPA, 2011).

Determination of texture and electrical conductivity of the saturated soil

Soil texture was determined for 30 samples (10 of each area) collected near the points used to measure hydraulic conductivity.

Soil sand, clay, and silt fractions were determined by the Boyoucus densimeter method, following the methodology proposed by Embrapa (2011). Salinity was determined using the saturated soil paste method (RICHARDS, 1954), and moisture was corrected based on the gravimetric method. The sand and clay fractions were used to show the texture composition of the three evaluated areas.

\section{Statistics and Spatial variability}

The data was subjected to descriptive statistics, determining mean, median, amplitude, quartiles, standard deviation, and coefficient of variation, which showed the dispersion and distribution of the variables. Data normality test was performed using the Kolmogorov-Smirnov test (K-S) at $5 \%$ probability.

The spatial dependence was then analyzed through geostatistics and semivariograms. The 
classical function for the semivariogram allows spatial autocorrelation between neighboring sites.

Semivariograms were developed using the Geoeas $^{\circledR}$ program. Then, gaussian, spherical, exponential, and linear models were tested. The fitting of the data to the experimental models showed the coefficients of the best theoretical model for the semivariogram, which were described as nugget effect $\left(C_{0}\right)$, sill $\left(C_{0}+\mathrm{C} 1\right)$, and range (a).

Cross-validation process was used; it consists of using an estimator to reevaluate the known sample values by calculating them one by one as if they were unknown (VAUCLIN et al., 1983).

The magnitude of spatial dependence (SD) in the semivariograms was classified as strong, moderate, or weak, according to the criteria proposed by Cambardella et al. (1994).
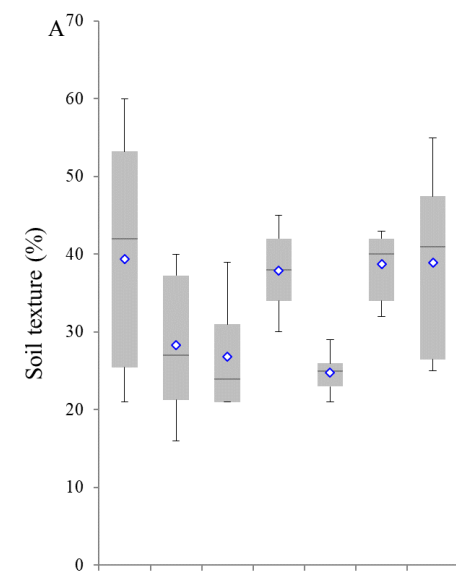

I
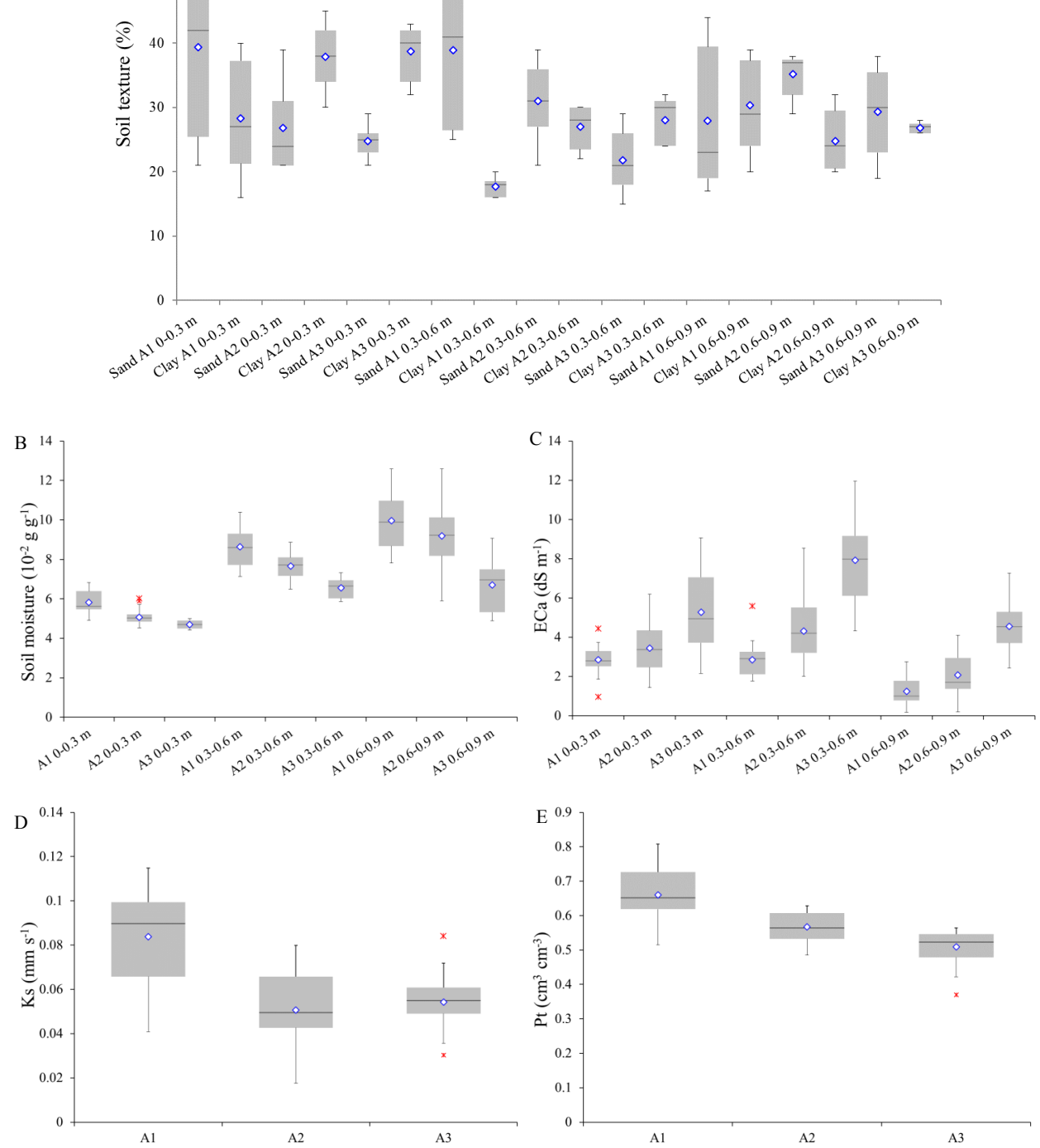

Figure 3. Box-plot of soil texture (A), moisture (B), apparent electrical conductivity (C), hydraulic conductivity (Ks) (D), and total porosity $(\mathrm{Pt})(\mathrm{E})$ for the preservation area (A1), fallow area (A2), and soil preparation area (A3) at the $0-0.3,0.3-$ 0.6 , and $0.6-0.9 \mathrm{~m}$ soil layers.

Rev. Caatinga, Mossoró, v. 32, n. 1, p. 222 - 233, jan. - mar., 2019 
Regarding the soil texture, more sandy profiles were found in $\mathrm{A} 1$ than in $\mathrm{A} 2$ and $\mathrm{A} 3$, although the $\mathrm{A} 2$ and $\mathrm{A} 3$ had varied values in the evaluated soil layers. Heterogeneous soils at surface and subsurface layers are common in alluvial valleys (MONTENEGRO; MONTENEGRO, 2006).

Greater soil moisture was found in A1, in the three evaluated layers. A3 presented the lowest moisture in all evaluated soil layers. The difference between areas was smaller in upper layers; deeper soil layers of the areas without soil coverage had very low moistures. Campos et al. (2013) found similar results, with statistically similar means to the Caatinga vegetation area and uncovered areas in the soil surface layer $(0-0.30 \mathrm{~m})$, denoting the great evapotranspiration of the Brazilian semiarid region.

A3 had discrepancies, with high ECa, and the ECa of A2 was lower than that of A1. The high soil salinity found is explained by external sources, since the natural environment does not have high soil salinity as the other areas that have been used for crops and had soil preparation with the use of fertilizers and irrigation.

A1 presented higher Ks than the other areas; it was associated with the natural vegetation, which favors water infiltration. Similarly, A1 had the highest total soil porosity (Figure $3 \mathrm{E}$ ), followed by A2 and A3, favoring ECa. Campos et al. (2013) found favorable microporosity, total porosity, and particle density in a natural forest area, which favors soil water dynamics.

According to Lima et al. (2015), river basins in the semiarid region of Pernambuco have reduced soil thicknesses and limited Ks, which tend to affect negatively natural drainage and lead to accumulation of salts in the soil profile.

Oliveira Júnior et al. (2014) evaluate the Ks of a preservation area in the Brazilian semiarid region, which resembles $\mathrm{A} 2$, and found a negative effect of pastures on hydrodynamic parameters, especially in $\mathrm{Ks}$; the area with Caatinga vegetation presented twice the Ks of the soil with crops.

Soil texture, moisture, and total porosity data showed that area A1 had, in general, good structure, better particle size arrangement, and greater moisture. According to Parente et al. (2010), these characteristics combined with the soil organic matter content improve soil hydraulic conductivity and water retention, allowing greater dispersion and leaching of salts.

Areas of alluvial valleys present heterogeneous soils, thus, the regressions for the EM $38^{\circledR}$ values provided important and accurate information that shows qualitative and quantitative variations of physical and chemical attributes of the soil profiles, mainly for soil management, as also pointed out by Montenegro et al. (2010).

Lesch et al. (1992) evaluated the same models used in the present study and found satisfactory results, thus, these models can be used for areas with different sizes and high salinity amplitude. Figure 4A shows the ECa transformed by the logarithm, and the high horizontal and vertical collinearities in the readings. The use of the difference $\ln \left(\mathrm{EM}_{\mathrm{H}}\right)-\ln$ $\left(E M_{V}\right)$ was efficient in removing such dependence (Figure 4B); this verification is part of the data validation process.

The Rhoades and Corwin (1981) model presented good accuracy for all layers (Figure 4C), with ECse (electrical conductivity of the saturated extract) and ECa data evaluated together, and a coefficient of determination of 0.86 . Thus, the measured and estimated data can be applied to the total depth, not requiring stratification. These results presented better fit when compared to those of Montenegro et al. (2010), and can be explained by the difference in texture, chemical composition, moisture, and calibration, as observed by Triantafilis, Ahmed and Odeh (2002) and Thiesson et al. (2014). 

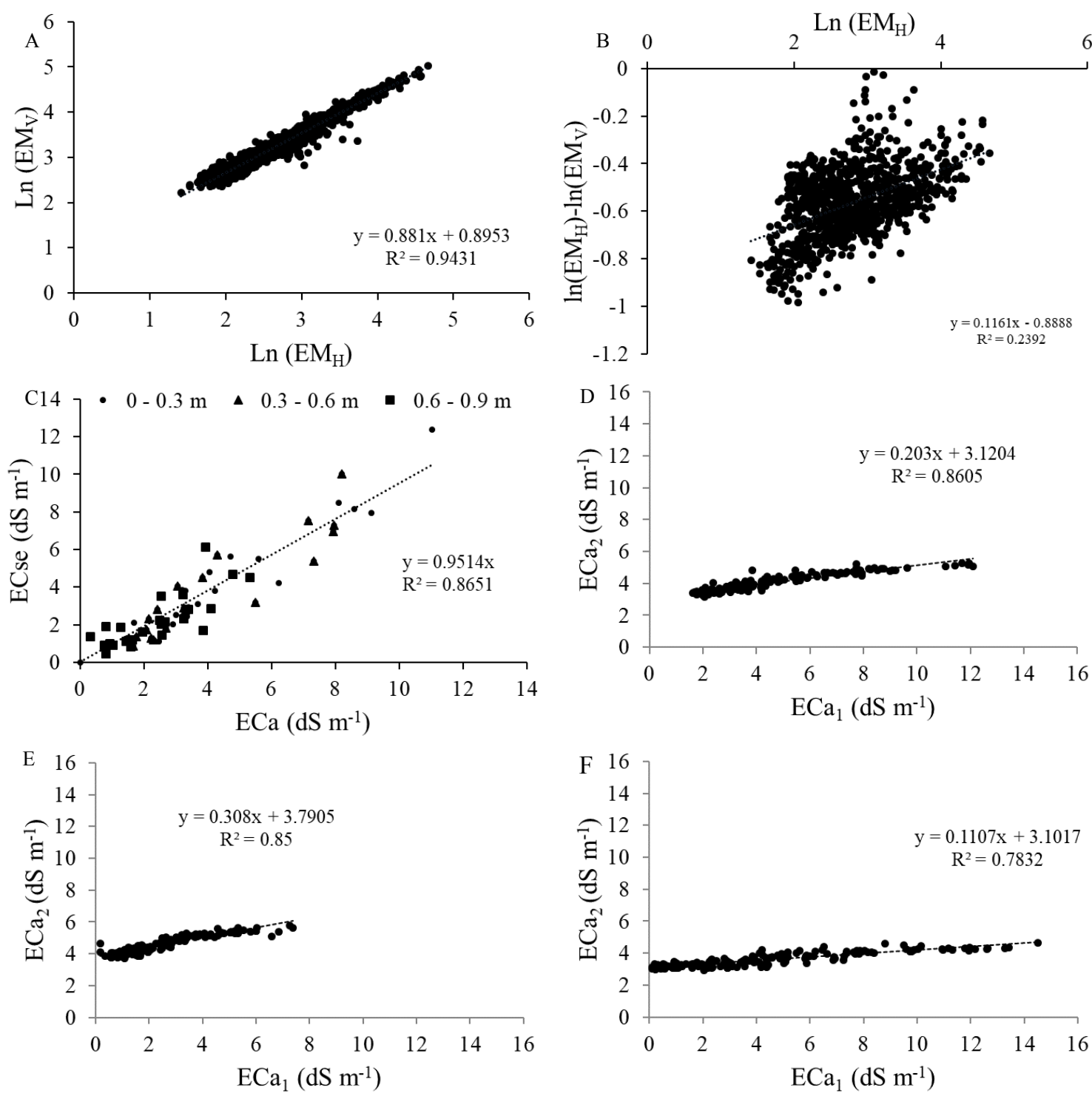

Figure 4. Relation of $\ln (\mathrm{EMH})$ with $\ln (\mathrm{EMV})(\mathrm{A})$; withdrawal of collinearity between $\ln (\mathrm{EMH})-\ln (\mathrm{EMV})$ and $\ln (\mathrm{EMH})$ (B); relation between ECa (estimated by Rhoades; Corwin, 1981) and ECse (electrical conductivity of the saturated extract) (C); and relation between ECa1 (estimated by Rhoades; Corwin, 1981) and ECa2 (estimated by Corwin, 1999) for the 0-0.3 $\mathrm{m}(\mathrm{D})$, 0.3-0.6 $\mathrm{m}(\mathrm{E})$, and 0.6-0.9 $\mathrm{m}(\mathrm{F})$ soil layers.

The Rhoades and Corwin (1981) model presented good accuracy for all layers (Figure 4C), with ECse (electrical conductivity of the saturated extract) and ECa data evaluated together, and a coefficient of determination of 0.86 . Thus, the measured and estimated data can be applied to the total depth, not requiring stratification. These results presented better fit when compared to those of Montenegro et al. (2010), and can be explained by the difference in texture, chemical composition, moisture, and calibration, as observed by Triantafilis and Ahmed; Odeh (2002) and Thiesson et al. (2014).

Since the application of the Rhoades and Corwin (1981) model was validated for the studied area, a correlation with the Rhoades, Chanduvi and Lesch (1999) model was performed. The values obtained by Rhoades, Chanduvi and Lesch (1999) were underestimated when compared to Rhoades and Corwin (1981), as showed in Figures 4D, 4E, and $4 \mathrm{~F}$, corresponding to the $0-0.3 \mathrm{~m}, 0.3-0.6 \mathrm{~m}$, and 0.6$0.9 \mathrm{~m}$ soil layers, respectively. However, this methodology was also validated, with coefficients of determination above 0.78. This shows a low sensitivity of the Rhoades, Chanduvi and Lesch (1999) model because this methodology uses mean values and presents a logarithmic conversion to obtain ECa values.

The descriptive statistical analysis (mean, median, variance, coefficient of variation $(\%)$, asymmetry coefficient, kurtosis coefficient, largest error, and Kolmogorov-Smirnov validation at 5\%) are presented in Table 2. 
Table 2. Results of descriptive statistical analysis.

\begin{tabular}{ccccccccc}
\hline Variable & Mean & Median & Variance & $\begin{array}{c}\text { Coef. of } \\
\text { variation (\%) }\end{array}$ & $\begin{array}{c}\text { Coef. of } \\
\text { asymmetry }\end{array}$ & $\begin{array}{c}\text { Coef. of } \\
\text { kurtosis }\end{array}$ & $\begin{array}{c}\text { Largest } \\
\text { error }\end{array}$ & KS 5\% \\
\hline EC 0-0.3 m & 3.7350 & 3.2966 & 2.7859 & 44.6881 & 1.1966 & 1.5541 & 0.1331 & 0.1870 \\
EC 0.3-0.6 m & 4.7989 & 4.1824 & 6.5144 & 53.1861 & 1.0358 & 0.3761 & 0.1582 & 0.1870 \\
EC 0.6-0.9 m & 2.4650 & 2.0252 & 2.5532 & 64.8234 & 0.8006 & -0.0656 & 0.1404 & 0.1870 \\
EC 0-0.3 m & 0.0521 & 0.0521 & 0.0000 & 11.4909 & 1.0128 & 0.3474 & 0.1454 & 0.1870 \\
EC 0.3-0.6 m & 0.0768 & 0.0763 & 0.0001 & 13.6365 & 0.4660 & 0.0241 & 0.0496 & 0.1870 \\
EC 0.6-0.9 m & 0.0878 & 0.0880 & 0.0004 & 21.3106 & -0.1004 & -0.3762 & 0.0494 & 0.1870 \\
Ks & 0.0603 & 0.0551 & 0.0006 & 40.4810 & 0.1744 & -0.5949 & 0.1159 & 0.1870 \\
\hline
\end{tabular}

All variables presented normality at $5 \%$ probability, allowing to obtain parameters of theoretical semivariograms with the experimental data (Table 3), showing the values of nugget effect
$\left(C_{0}\right)$, sill $\left(C_{0}+\mathrm{C}\right)$, range $(\mathrm{A})$, and spatial dependence level (SD) of the tested models (exponential, spherical, and Gaussian).

Table 3. Parameters of the theoretical models for the semivariance of the soil variables measured, and the Jack-Knifing test.

\begin{tabular}{cccccccccc}
\hline & & & & \multicolumn{4}{c}{ Cross validation } & \multicolumn{3}{c}{$\mathrm{C}^{2}$} & $\mathrm{SD}^{*}$ \\
\hline Moisture 0-0.3 m & Spherical & 0.004 & 0.318 & 0.314 & 86.0 & 0.001 & 1.237 & 0.834 & 0.012 \\
Moisture 0.3-0.6 m & Spherical & 0.008 & 0.876 & 0.868 & 72.3 & 0.093 & 0.749 & 0.745 & 0.009 \\
Moisture 0.6-0.9 m & Spherical & 0.1 & 3.215 & 3.115 & 72.1 & 0.026 & 0.998 & 0.809 & 0.031 \\
ECa 0-0.3 m & Spherical & 1.173 & 3.992 & 2.819 & 410.9 & 0.016 & 1.163 & 0.847 & 0.291 \\
ECa0.3-0.6 m & Spherical & 1.4 & 9.809 & 8.409 & 377.9 & 0.007 & 1.151 & 0.898 & 0.142 \\
ECa0.6-0.9 m & Spherical & 0.46 & 3.93 & 3.47 & 359.9 & 0.005 & 0.812 & 0.95 & 0.117 \\
Ks & Gaussian & 0.0002 & 0.00057 & 0.00037 & 134 & 0.016 & 0.996 & 0.972 & 0.351 \\
Moisture x EC 0-0.3 m & Gaussian & -0.001 & -2.003 & -2.002 & 711.7 & --- & --- & 0.895 & 0.001 \\
Moisture x EC 0.3-0.6 m & Gaussian & -0.001 & -2.011 & -2.01 & 293.9 & --- & --- & 0.96 & 0.001 \\
Moisture x EC 0.6-0.9 m & Gaussian & -0.001 & -1.922 & -1.922 & 184.3 & --- & --- & 0.962 & 0.001 \\
\hline
\end{tabular}

$\mathrm{MR}=$ Mean of Residues; SDR = Standard Deviation of Residues; $\mathrm{SD}=$ Spatial dependence

Although some attributes had $\mathrm{R}^{2}$ lower than 0.90, the semivariograms had cross-validation through the Jack-Knifing methodology (VAUCLIN et al., 1983), yielding residues with averages between 0.001 and 0.093 , and standard deviations between 0.749 and 1.237. Silva et al. (2010) applied this methodology for mapping sand in the $0-0.2 \mathrm{~m}$ layer of an alluvial soil in the Agreste region of Pernambuco, and estimated, by interpolation, values of the variables for non-sampled sites, allowing the development of maps of greater precision.

$\mathrm{ECa}$ parameters were estimated using the EM $38^{\circledR}$ values, by applying Rhoades and Corwin (1981) model, validated by the correlations with the ECse. The ECa of A1 (natural preservation area) may be associated with the silt fraction (SOUZA et al., 2008), however, the variances of the other two areas were associated with the possible presence of fertilizers, especially in the area that was again being prepared for irrigated crops.

Ks presented a Gaussian model, with a range of $134 \mathrm{~m}$. Montenegro and Montenegro (2006), and Santos et al. (2012) found that the Gaussian model had best fit to semivariance when evaluating Ks. These two studies had similar spacing, and different scale to those of the present study.

Considering information on the Ks spatial distribution and soil texture variation, AlarcónJiménez, Camacho and Bernal (2015) stated that the soil salinity variability can present the same variance and, consequently, can be dependent on management.

The cross-variance between moisture and ECa showed an atypical result, because the moisture increases $\mathrm{EM} 38^{\circledR}$ values; ECa is the response of several parameters that affect the flow of electrons in porous media, such as moisture (GEONICS, 1999).

An inverse relation of moisture and ECa was found, i.e., the greater the variance of one the smaller variance of the other. However, a high range value was found, with good coefficients of correlation for all evaluated soil layers. 
The studied area had a high ECa variation. Thus, the effect of moisture is low and presents an inverse correlation. Therefore, the evaluation of moisture through ECa is not compromised, making it possible to obtain moisture values through ECa for points that were not sampled.

The savings in resources that occurred was also observed by Bottega et al. (2014) for the estimation of soil parameters by EC in soils altered by agriculture. Molin and Faulin (2013) found variation in electrical conductivity as a function of
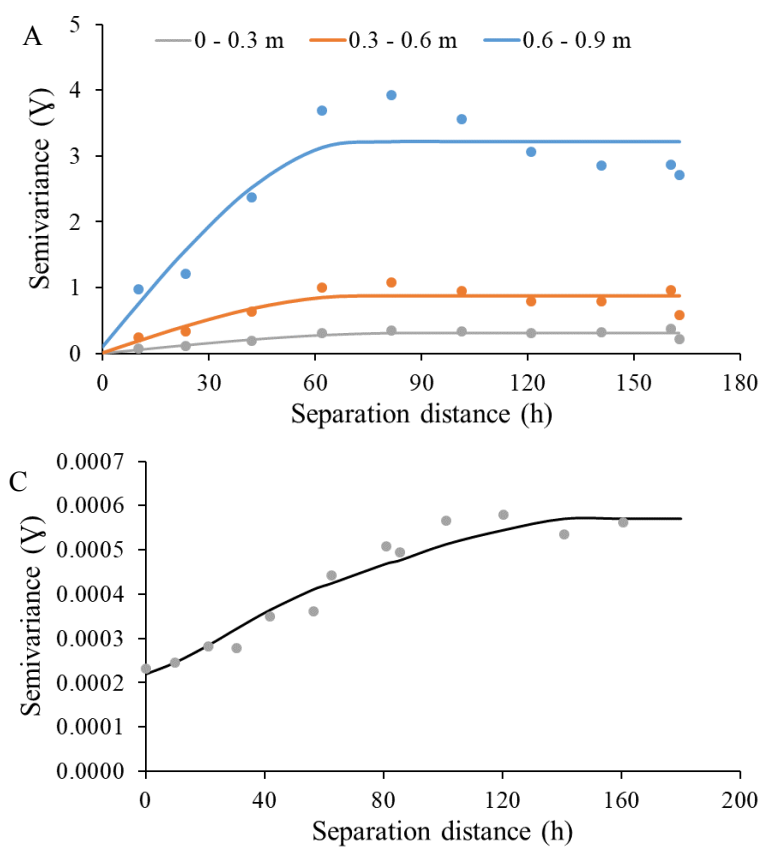

Figure 5. Semivariograms of the moisture of the $0-0.3 \mathrm{~m}, 0.3-0.6 \mathrm{~m}$, and $0.6-0.9 \mathrm{~m}$ soil layer (A), ECa of the $0-0.3 \mathrm{~m}, 0.3-$ 0.6 m, and 0.6-0.9 m soil layer (B), Ks (C), and moisture $\times \mathrm{ECa}$ of the 0-0.3 m, 0.3-0.6 m, and 0.6-0.9 m soil layer (D).

According to the semivariograms, the sill of the ECa (0-0.3 m, 0.3-0.6 m, and 0.6-0.9 m) (Figure $5 \mathrm{~B})$, and moisture $\times \mathrm{ECa}(0-0.3 \mathrm{~m}$, and 0.3-0.6 m) (Figure 5D) are not noticed. Thus, the minimum amount of 40 pairs of points was extrapolated and they are still within the greatest distance between points in the area, and others have extrapolated both. The ECa $(0-0.3 \mathrm{~m})$ and moisture $\times$ ECa $(0-0.3 \mathrm{~m})$ extrapolated the limits of the area, thus, it would be more convenient to evaluate them in a grid that covers a larger area.

Considering the high coefficients of determination of the theoretical models fitted to the cross-semivariance, the moisture $\times \mathrm{ECa}$ maps were developed using the cokriging technique. They presented greater similarity to moisture spatial distribution than those developed with kriging.

Despite the different variances, the semivariograms for soil moisture had similar results,
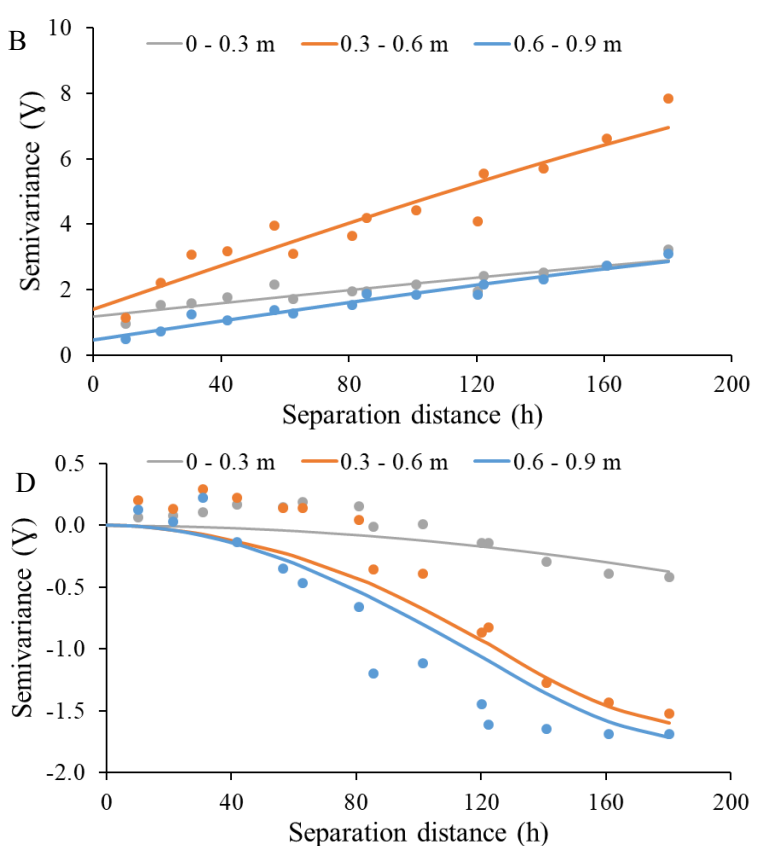

soil moisture in areas with more homogeneous ECa, thus, suggesting that moisture is a good indicator of soil quality.

The parameters of the theoretical semivariograms fitted to the experimental data allowed the elaboration of semivariance graphs (Figures 5A, 5B, 5C, and 5D). The semivariograms were generated for the entire area and individualized for the three evaluated soil layers, except Ks, which was evaluated in the surface layer.

thus, the surveying must be carried out with equal grids and spacing of smaller range value in soils with different uses or coverages, denoting the textural variation and, consequently, variation in water storage of alluvial soils.

The three soil layers had similar ECa, and did not present sill; thus, the correlation lengths were larger than the size of the study area. The increases in the semivariances $(0.3-0.6 \mathrm{~m})$ were high, probably because this region is strongly affected by combined infiltration and capillary processes. This causes greater variability in the results, as seen in the ECa box-plots.

The maps for soil moisture, salinity (ECa), and $\mathrm{Ks}$, and moisture $\times$ ECa covariance (Figure 6) showed higher moisture and Ks gradients at first distances, and higher salinity in the region near the northeast end. 


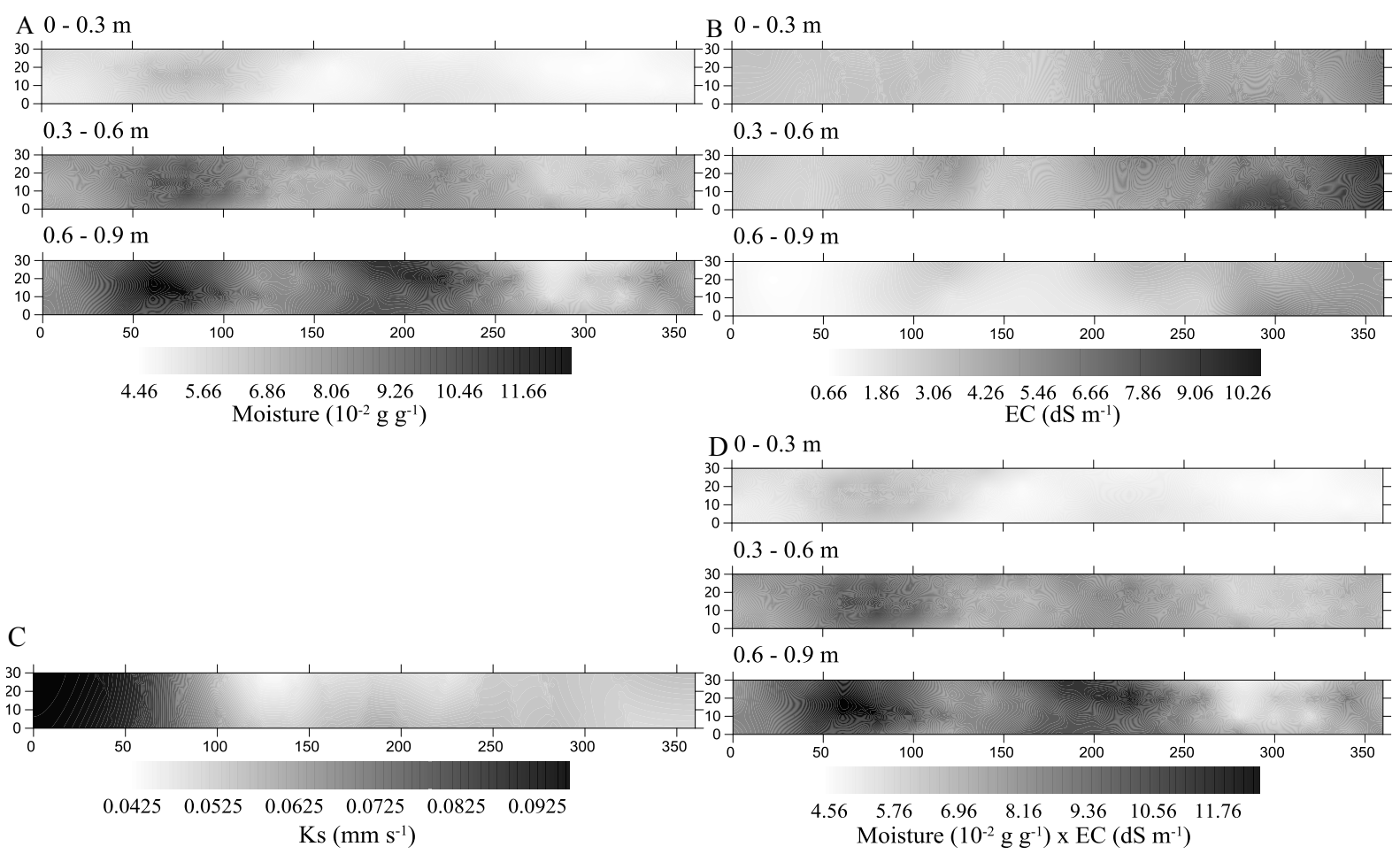

Figure 6. Kriging maps for moisture (A), apparent electrical conductivity (B), hydraulic conductivity (C), and cokriging maps for moisture $\mathrm{x} \mathrm{ECa}(\mathrm{D})$.

A1 presented the highest moistures, especially in the $0-0.3 \mathrm{~m}$ soil layer. This may be associated with the mulching effect of the Caatinga vegetation due to the deciduous vegetation. Monte-Mor et al. (2012) observed a mulching effect in northern Minas Gerais (semiarid region), Brazil, due to the formation of a leaf layer on the soil, which improved the seed germination process of Caatinga species. In addition, the $0-0.3 \mathrm{~m}$ (sandy soil layer) acts as an extinguishing zone of ascending capillary flows, contributing to the maintenance of water in the profile.

Montenegro et al. (2013) evaluated the reduction of soil and water losses due to natural mulching and found a a significant and rapid increase in soil moisture due to the mulching.

The Ks in A1 was also favored by the mulching effect. This vegetation causes a constant rearrangement of the soil, making its structure more porous, with an infiltration speed that slows runoff when compared with the other areas.

The maps developed with parameters of cross -semivariograms and fitted to theoretical models showed moisture for points where measurements were not performed, thus, the moisture evaluations for precision agriculture can be performed by reading electromagnetic induction. This methodology is similar to that described by Costa et al. (2014), who mapped soil attributes with precise interpretation and recommendation of managements that can generate economic savings.

\section{CONCLUSIONS}

The electromagnetic induction equipment $\left(E M 38^{\circledR}\right)$ used was efficient to verify the presence of salts in the alluvial soil of the Brígida River valley, in Panamirim, state of Pernambuco, Brazil. The equipment was properly calibrated and the results were validated.

The area evaluated has high texture heterogeneity, typical of alluvial soils, with increasing clay contents with increasing soil depth.

The soil cover promoted the maintenance of soil moisture, contributing to the development and maintenance of the vegetal biomass of the riparian forest.

The mulching effect due to the deciduous characteristic of the Caatinga vegetation was important to the maintenance of soil moisture.

Caatinga vegetation contributes to the maintenance of soil structure, favoring surface infiltration speed, and ecosystem services of riparian vegetations.

The indirect methodology used allows the accurate measurement of soil moisture of nonsampled sites from the ECa, reducing uncertainties in spatial estimates.

\section{ACKNOWLEDGMENTS}

To the National Council for Scientific and Technological Development (CNPq), the Funding 
Agency for Studies and Projects (FINEP) and the Foundation for Science and Technology Support of the Pernambuco State (FACEPE) for supporting the development of the research. We also thank $\mathrm{Mr}$. Eurico Lustosa and Mr. Edson Abrantes, for the local support.

\section{REFERENCES}

ALARCÓN-JIMÉNEZ, M. F.; CAMACHO, J. H.; BERNAL, J. H. Management zones based on corn yield and soil physical attributes. Agronomía Colombiana, v. 3, n. 33, p. 373-382, 2015.

BORRELLI, P. et al. Wind erosion susceptibility of European soils. Geoderma, v. 23, n. 4, p. 471-478, 2014.

BOTTEGA, E. L. et al. Estimativa de valores granulométricos do solo em locais não amostrados utilizando-se cokrigagem. Agrária, v. 9, n. 2, p. 244 $250,2014$.

CAMBARDELLA, C. A. et al. Field scale variability of soil properties in central Iowa soil. Soil Science Society of America Journal, v. 47, n. 5, p. 15011511, 1994.

CAMPOS, M. C. C. et al. Variabilidade espacial dos atributos físicos em um argissolo vermelho sob floresta. Comunicata Scientiae, v. 4, n. 2, p. 168178, 2013.

CORWIN, D. L.; LESCH, S. M. Applications of soil electrical conductivity to precision agriculture: Theory, principles, and guidelines. Agronomy Journal, v. 95, n. 3, p. 455-471, 2003.

CORWIN, D. L. Applications of apparent soil electrical conductivity in precision agriculture. Computers and Electronics in Agriculture, v. 46, n. 1, p. 1-10, 2005.

COSTA, M. M. et al. Moisture content effect in the relationship between apparent electrical conductivity and soil attributes. Acta Scientiarum. Agronomy, v. 36, n. 4, p. 395-401, 2014

EMPRESA BRASILEIRA DE PESQUISA AGROPECUÁRIA - EMBRAPA. Manual de métodos de análises de solos. 3. ed. Rio de Janeiro, RJ: Embrapa Solos, 2011. 230 p.

GEONICS, EM 38. Ground conductivity meter operating manual. 1. ed. Ontário: GEONICS Ltd. 1999. $69 \mathrm{p}$.

GOLDEN SOFTWARE. Surfer: User's Guide (Version 7.0). 1. ed. EEUU: Golden Software, 1999.
679 p.

GUO, Y. et al. Mapping spatial variability of soil salinity in a coastal paddy field based on electromagnetic sensors. PloS one, v. 10, n. 1, e0127996, 2015.

HAVERKAMP, R. et al. Soil properties and moisture movement in the unsaturated zone. 1. ed. Abingdon: Taylor \& Francis Group, 1998. 130 p.

LABORCZI, A. et al. Mapping of topsoil texture in Hungary using classification trees. Journal of Maps, v. 12, n. 5, p. 999-1009, 2015.

LASSABATÈRE, L. et al. Beerkan estimation of soil transfer parameters through infiltration experiments - BEST. Soil Science Society of American Journal, v. 70, n. 2, p. 521-532, 2006.

LESCH, S. M. et al. Mapping soil salinity unsing calibrated electromagnetic measurements. Soil Science Society of America Journal, v. 56, n. 2, p. 540-548, 1992.

LIMA, J. W. et al. Comparative hydrology: relationships among physical characteristics, hydrological behavior, and results of the SWAT model in different regions of Brazil. Revista Brasileira de Geografia Física, v. 7, n. 6, p. 1187 1195, 2015.

LOPES, I. et al. Análise multivariada no estudo da variação do Índice de Aridez da Bahia e Pernambuco. Agrometeoros, v. 26, n. 1, p. 93-102, 2018.

LOPES, I. et al. Balanço hídrico em função de regimes pluviométricos na região de Petrolina-PE. Irriga, v. 22, n. 3, p. 443-457, 2017.

MOLIN, J. P.; FAULIN, G. D. C. Spatial and temporal variability of soil electrical conductivity related to soil moisture. Scientia Agricola, v. 70, n. 1, p. 1-5, 2013.

MONTE-MOR, R. C. A. et al. Estabilidade temporal da distribuição espacial da umidade do solo em uma bacia intermitente no semiárido de Minas Gerais. Revista Brasileira de Recursos Hídricos, v. 17, n. 3, p. 101-113, 2012.

MONTENEGRO, A. A. A. et al. Avaliação da salinidade de Neossolo usando-se dispositivo de indução eletromagnética. Revista Brasileira de Engenharia Agrícola e Ambiental, v. 14, n. 6, p. 608-617, 2010.

MONTENEGRO, A. A. A. et al. Impact of Mulching on Soil and Water Dynamics under Intermittent 
Simulated Rainfall. Catena, v. 109, n. 1, p. 139-149, 2013.

MONTENEGRO, A. A. A.; MONTENEGRO, S. M. G. L. Variabilidade espacial de classes de textura, salinidade e condutividade hidráulica de solos em planície aluvial. Revista Brasileira de Engenharia Agrícola e Ambiental, v. 10, n. 1, p. 30-37, 2006.

OLIVEIRA JUNIOR, J. A. S. et al. Variabilidade espacial de propriedades hidrodinâmicas de um Neossolo Regolítico sob pastagem e caatinga. Revista Brasileira de Engenharia Agrícola e Ambiental, v. 18, n. 6, p. 631-639, 2014.

PARENTE, H. N.; et al. Impacto do pisoteio caprino sobre atributos do solo em área de caatinga. Revista Brasileira de Saúde e Produção Animal, v. 11, n. 2, p. 331-341, 2010.

RHOADES, J. D.; CHANDUVI, F.; LESCH, S. Soil salinity assessment methods and interpretation of electrical conductivity measurements. 57 . ed. Rome: FAO, 1999. 155 p.

RHOADES, J. D.; CORWIN, D. L. Determining soil electrical conductivity - depth relations using inductive electromagnetic soil conductivity meter. Soil Science Society America Journal, v. 45, n. 2, p. 54-60, 1981.

RHOADES, J. D. et al. New calibrations for determining soil electrical conductivity-depth relations from electromagnetic measurements. Soil Science Society America Journal, v. 53, n. 1, p. 7479, 1989.

RICHARDS, L. A. Diagnosis and improvement of saline and alkali soils. 1. ed. Washington, DC: AGRICULTURE HANDBOOK, 1954. 160 p.

SANTOS, K. S. et al. Variabilidade espacial de atributos físicos em solos de vale aluvial no semiárido de Pernambuco. Revista Brasileira de Engenharia Agrícola e Ambiental, v. 16, n. 8, p. 828-835, 2012.

SCHLOSSER, K. et al. A geophysical field investigation of infiltration during rain events in the riparian zone. Geological Society of America, v. 45, n. 7 , p. 263, 2013.

SILVA, J. J. M. et al. Avaliação da salinidade de Neossolo usando-se dispositivo de indução eletromagnética. Revista Brasileira de Engenharia Agrícola e Ambiental, v. 14, n. 6, p. 608-617, 2010.
Neossolo Flúvico no semiárido. Ciência Rural, v. 38, n. 2, p. 698-704, 2008.

THIESSON, J. et al. Calibration of frequencydomain electromagnetic devices used in near-surface surveying. Near Surface Geophysics, v. 12, n. 4, p. 481-491, 2014

TRIANTAFILLIS, J.; AHMED, M. F.; ODEH, I. O. A. Application of a mobile electromagnetic sensing system (MESS) to assess cause and management of soil salinitization in an irrigated cotton-growing field. Soil Use and Management, v. 18, n. 4, p. 330$339,2002$.

VAUCLIN, M. et al. The use of cokringing with limited field soil observation. Soil Science Society of America Journal, v. 47, n. 1, p. 175-184, 1983.

VIDON, P. Towards a better understanding of riparian zone water table response to precipitation events: surface water infiltration, hillslope contribution, or pressure wave processes? Hydrological Processes, v. 26, n. 21, p. 3207-3215, 2012.

YAO, R. J.; YANG, J. S.; LIU, G. M. Calibration for soil electromagnetic conductivity in invertd salinity profiles with an integration method. Pedosphere, v. 17, n. 2, p. 246-256, 2007.

SOUZA, E. R. et al. Variabilidade espacial das frações granulométricas e de salinidade em um 